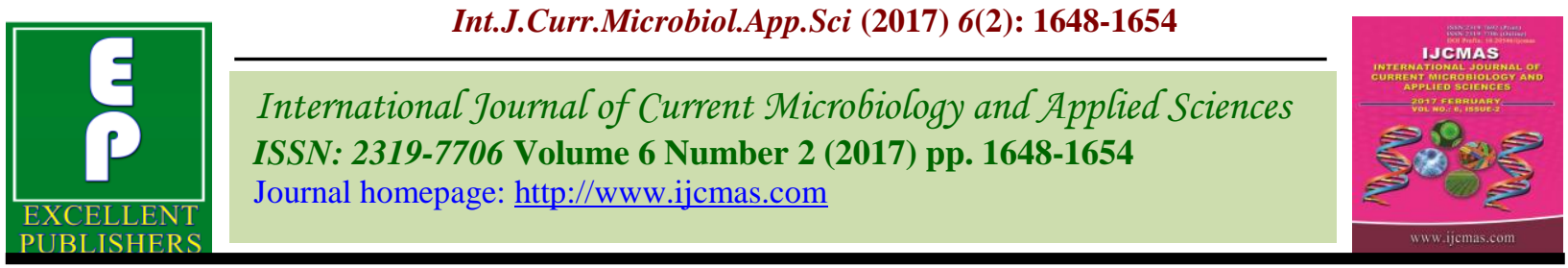

Original Research Article

http://dx.doi.org/10.20546/ijcmas.2017.602.184

\title{
Situational Effect about Rural Girls in Faizabad District
}

\author{
Shalini Srivastava*, Prakash Singh and Manoj Kumar \\ Department of Extension Education, NDUA\&T., Kumarganj, Faizabad-224229 (UP), India \\ *Corresponding author
}

\section{A B S T R A C T}

\begin{tabular}{|l|}
\hline Ke y w o r d s \\
$\begin{array}{l}\text { Faizabad, Rural } \\
\text { girls, Situation } \\
\text { effect, Mass media }\end{array}$ \\
\hline Article Info \\
\hline $\begin{array}{l}\text { Accepted: } \\
\text { 24 January } 2017 \\
\text { Available Online: } \\
\text { 10 February } 2017\end{array}$ \\
\hline
\end{tabular}

\section{Introduction}

Family is a basic social unit consisting of parents and their children, considered as a group, whether dwelling together or not. When explaining academic achievement problems, people tend to focus on the two primary socialization agents of children: the home and the school. While the home and school environments are often directly linked to school performance, they also help shaped personality variables that are also directly linked to school performance. In particular, Researchers have investigated personality issues such as self-esteem, self-confidence, and handling evaluative anxiety as important issues that relate both to family and school environment as well as to academic achievement. Parenting styles and family environment factors are related to failureavoidant strategies (Eccles et al., 1996). Authoritative parenting results in success-

Seeking where as authoritarian parenting leads to failure-avoidance (Leung \& Kwan, 1998). In Addition, mixed family messages about achievement (Thompson, 2001), family over control and conflict (Bussotti, 1990), family achievement orientation (King \& Cooley, 1995), and lack of family cohesion (Hein \& Lewko, 1994) have all been related to failure avoidant tendencies. Parenting style 
and family environment may also contribute to the development of personality characteristics such as uncertainty about self, low self-esteem, and evaluation anxiety that lead to the development of failure-avoidant tendencies (Thompson, 1999). In particular, authoritarian parenting styles and a family environment of conflict, over control, and lack of cohesion have been shown to result in low self-esteem and self-confidence in children as well as in a lack of ability to successfully handle anxiety and stress (e.g., Buri, 1988; Hoelter \& Harper, 1987; Killeen, 1993).Keeping in view the above facts into consideration this study was undertaken on the following specific objectives; To study the socio- economic profile of rural girls students. To study the Situational effect about rural girls students.

\section{Materials and Methods}

Faizabad district of Uttar Pradesh will be selected purposively for convenience of investigator and the N.D. University of Agriculture \& Technology Kumarganj falls in this district. There are (11) blocks in Faizabad district of which (06) blocks are considered as forward blocks, while (05) blocks are medium blocks. One block from each category will be selected randomly for the purpose of further investigation, thus makes a total of 02 blocks. A list of all the villages in each block will be procured from block headquarter and arranged according to total population. Four villages from each block which are having highest population will be selected, thus makes a total of 08 villages. At this stage, the list of girls who are studying in High school, Intermediate and Graduation will be prepared separately for each selected village. Thereafter, a total of 160 girls as respondents would be selected though proportionate random sampling technique keeping in view the categories of education (High school, Intermediate and Graduation).

\section{Results and Discussion} Socio- economic profile of rural girl
students

Age: It is obvious from the Table I-A. that maximum number of the respondents $(36 \%$, $43 \%$ ) was observed in the category of up to 14 years of age followed by 15 to 19 years $(36 \%, 43 \%)$ and 20 to above $(30 \%, 18 \%)$ respectively. So, it focuses that the rural girl students of 15 to 19 years of age category were observed to be more.

Education: the Table I-B. reveals that all students/respondents were found in the Intermediate 33\% (Milkipur) 35\% (Masodha), Graduation 33\% (Milkipur) 25\% Masodha) and High school in 32\% (Milkipur) and 40\% (Masodha), girl students respectively.

Caste: the Table I-C. Indicates the little less than half of the respondents (46\% \& 40\%) belonged to general categories of caste while the backward caste and scheduled caste were $21 \%$ in Milkipur 26\% Masodha and 32\%, $33 \%$ respectively. Thus, it can be concluded that general caste had dominancy so for as rural girls study is concerned.

Economic motivation: It is apparent from Table I-D. That a maximum number of respondents (76\% Milkipur and 53\% Masodha) was found having medium level of economic motivation, while (11\% Milkipur and 36\% Masodha) and (12\% Milkipur and $22 \%$ Masodha) respondents were such who had high and low levels of economic motivation, respectively.

Motivational sources: It is evident from the Table I-E. (Milkipur) that the maximum 36\% respondents was motivate by father, followed by Newspaper, mother, self, friend, $22 \%$, $10 \%, 08 \%$ and $05 \%$ respectively were found to be important motivational sources among all. 
Value orientations: It is apparent from the Table I-F. That 43.75 per cent and 75 per cent of the respondents were found having medium level of value orientations followed by $(21 \%, 13 \%)$ and $35 \%, 11 \%)$ who had high and low levels respectively.

Extent of contact with information sources: The data furnished in the Table I-G. Pertain to extent of contact of respondents with different information sources as used by them for receiving general information's. So for as contact with formal sources was concerned, class teachers Dean of College, teacher of mother university, school teachers, teachers of other university, primary teachers, placement bureau. As far as contact with informal sources was concerned, friends, seniors, family members, neighbor, relatives. Among the mass media sources, radio, local newspaper, T.V., news bulletins, magazines, nationals newspaper, feature film, employment newspaper. The formal and mass media information sources were also utilized by the respondents with considerable extent.

Family type: The Table I-H. Indicates that 68 per cent (Milkipur) 72 per cent (Masodha) respondents were residing in nuclear family system while remaining 31 per cent (Milkipur) 27 per cent (Masodha) respondents were observed in joint family system.

Family size: It is evident from the Table I-I. That 47.50 per cent (Milkipur) and 55 per cent (Masodha) respondent's families were observed such who had 5 to 7 members. The 32.50 per cent in Milkipur and 28.75 per cent Masodha families were having below to 4 members, 8 and above members were 20 per cent (Milkipur) and 16.25 per cent (Masodha) only.

Housing pattern: It is evident from the Table I-J. That 53.75 per cent (Milkipur) and 42.50 per cent (Masodha) respondents were observed such who had mixed type house.
The 45.00 per cent in Milkipur and 57.50 per cent Masodha families were having pucca and hut type house were 01 per cent (Milkipur) only.

Family occupation: The Table I-K. Reveals the main and subsidiary family occupations of the respondents. In case of main occupation the highest no. of respondents (55\%) reported agriculture as their main family occupation followed by service $(18.75 \%)$, business $(17.50 \%)$, and dairying (3\%) respectively. Similarly in case of subsidiary occupation, maximum no. of respondents $(25 \%)$ reported agriculture as their main subsidiary occupation followed by dairying (6.25\%), business $(5 \%)$ in descending orders. Hence, the agriculture was seen as important main occupation and the business as subsidiary.

Annual income of family: It is obvious from Table I-L. that a maximum number of the respondents (33.75\%) in Milkipur block and $63.75 \%$ respondents in Masodha block was from those families whose annual income were found in the category of Rs. 75,000 to $1,50,000$ and $1,80,001$ to $2,70,000$ followed by other categories viz., 17 per cent (Rs. 1,50,001 to 2,25,000), 7 per cent (above Rs. $3,00,001 \mathrm{~b} 1)$ and 5 per cent $(3,60,001$ and above b2) respectively..

Communication media possession: The Table I-M. Shows that a majority of respondents in Milkipur block $(97 \%)$ at personal level was observed possessing book with them and at family level (90\%) was observed possessing news paper and 91 per cent respondents as cellular phone, 85 per cent television and 81 per cent news paper. At family level (Masodha) the person who had other communication media with them were in descending order as newspaper (93\%), cellular phone (96\%), telephone (43\%), radio (72\%), computer (76\%), book $100 \%)$, journal (30\%), magazine (75\%), and periodicals (18\%) respectively. Hence, it may be 
concluded that the respondents as well as their families have a good no. of communication media possession.

Land holding: The Table I-N. indicate that more than half of the respondent $(46 \%$ and $45 \%$ ) were found in the large and medium category followed by small and marginal farmers $(22 \%, 10 \%)$ and land less $(7 \%)$. Land fewer farmers in Masodha block (23\%), Medium farmers (13\%) (2-3 hect) small farmers (12\%) (1-2 hect) and Masodha block was marginal farmers (4\%) (Below- 1, hect.) Respectively.
Decision pattern of family: Table I-O. Indicates that the majority of respondents in decision pattern of family father $(56.75 \%)$, mother $(41.25 \%)$, and brother $(01.75 \%)$ in family affairs respectively.

Agricultural matters in father (74.25\%), mother (24.25\%), and brother (1.29\%) respectively. Occupation matters in services, business and agriculture category father $(81.45 \%)$, mother $(15.00 \%)$ and brother $(01.87 \%)$ respectively.

Socio- economic profile of rural girl's students

\begin{tabular}{|c|c|c|c|}
\hline S.No. & Age categories & $\begin{array}{c}\text { Respondents } \\
\text { B1 }(\%)\end{array}$ & $\begin{array}{c}\text { Respondents } \\
\text { B2 }(\%)\end{array}$ \\
\hline 1. & Up to 14 years & 33.75 & 37.50 \\
\hline 2. & 15 to 19 years & 36.25 & 43.75 \\
\hline \multirow[t]{2}{*}{3.} & 20 to above & 30.00 & 18.75 \\
\hline & \multicolumn{3}{|l|}{ Education } \\
\hline 1. & High school & 32.5 & 40.00 \\
\hline 2. & Intermediate & 33.75 & 35.00 \\
\hline \multirow[t]{2}{*}{3.} & Graduation & 33.75 & 25.00 \\
\hline & \multicolumn{3}{|l|}{ Caste } \\
\hline 1. & General caste & 46.25 & 40.00 \\
\hline 2. & Backward caste & 21.25 & 26.25 \\
\hline \multirow{2}{*}{3.} & Scheduled caste & 32.50 & 33.75 \\
\hline & \multicolumn{3}{|l|}{ Economic motivation } \\
\hline 1. & Low (up to 17) & 12.50 & 22.50 \\
\hline 2. & Medium(18-23) & 76.25 & 53.75 \\
\hline \multirow[t]{2}{*}{3.} & High (24- above) & 11.25 & 36.25 \\
\hline & \multicolumn{3}{|l|}{ Motivational sources } \\
\hline 1. & Mother & 10.00 & 12.50 \\
\hline 2. & Father & 36.25 & 31.25 \\
\hline 3. & Teachers & 03.75 & 08.75 \\
\hline 4. & Brother & 01.25 & 02.50 \\
\hline 5. & T.V. & 01.25 & 02.50 \\
\hline 6. & Newspaper & 22.50 & 18.75 \\
\hline \multirow[t]{2}{*}{7.} & Friends & 05.00 & 05.00 \\
\hline & \multicolumn{3}{|l|}{ Value orientations } \\
\hline 1. & Low (up to 33) & 35.00 & 11.25 \\
\hline 2. & Medium (34-38) & 43.75 & 75.00 \\
\hline 3. & High (39 and above) & 21.25 & 13.75 \\
\hline
\end{tabular}




\begin{tabular}{|c|c|c|c|c|c|}
\hline A. & $\begin{array}{l}\text { Information sources } \\
\text { Formal sources }\end{array}$ & \multicolumn{2}{|c|}{$\begin{array}{l}\text { Mean score } \\
\text { value (B1) }\end{array}$} & \multicolumn{2}{|c|}{$\begin{array}{l}\text { Mean score } \\
\text { value(B2) }\end{array}$} \\
\hline 1. & Class teachers & \multicolumn{2}{|c|}{0.635} & \multicolumn{2}{|c|}{0.687} \\
\hline 2. & Dean of college & \multicolumn{2}{|c|}{0.452} & \multicolumn{2}{|c|}{0.564} \\
\hline 3. & Placement bureau & \multicolumn{2}{|c|}{0.310} & \multicolumn{2}{|c|}{0.450} \\
\hline 4. & Teachers of mother university & \multicolumn{2}{|c|}{0.389} & \multicolumn{2}{|c|}{0.531} \\
\hline 5. & Teachers of other university & \multicolumn{2}{|c|}{0.427} & \multicolumn{2}{|c|}{0.577} \\
\hline 6. & School teacher & \multicolumn{2}{|c|}{0.468} & \multicolumn{2}{|c|}{0.618} \\
\hline 7. & Primary teacher & \multicolumn{2}{|c|}{0.479} & \multicolumn{2}{|c|}{0.60} \\
\hline B. & Informal sources & & & & \\
\hline 1. & Friends & \multicolumn{2}{|c|}{0.889} & \multicolumn{2}{|c|}{0.80} \\
\hline 2. & Seniors & \multicolumn{2}{|c|}{0.814} & \multicolumn{2}{|c|}{0.766} \\
\hline 3. & Family members & \multicolumn{2}{|c|}{0.902} & \multicolumn{2}{|c|}{0.902} \\
\hline 4. & Neighbors & \multicolumn{2}{|c|}{0.704} & \multicolumn{2}{|c|}{0.743} \\
\hline 5. & Relatives & \multicolumn{2}{|c|}{0.810} & & \\
\hline C. & Mass media exposure & & & & \\
\hline 1. & Radio & & & & 33 \\
\hline 2. & T.V. & & & & 75 \\
\hline 3. & Feature film & & & & 02 \\
\hline 4. & Poster & & & & \\
\hline 5. & News bulletins & & & & \\
\hline 6. & Magazines & & & & \\
\hline 7. & Newspaper & & & & \\
\hline & Family type & & & & \\
\hline 1. & Nuclear & & & & 50 \\
\hline 2. & Joint & & & & 50 \\
\hline & Family size & & & & \\
\hline 1. & Bel0w 4 members & & & & 75 \\
\hline 2. & 5 to 7 members & & & & 00 \\
\hline 3. & 8 members and above & & & & 25 \\
\hline & Housing pattern & & & & \\
\hline 1. & Hut & & & 00.00 & \\
\hline 2. & Mixed & & & 42. & \\
\hline 3. & Pucca & & & & \\
\hline & Family occupation & M\% & S \% & M\% & $\mathrm{S} \%$ \\
\hline 1. & Agriculture labour & 01.25 & 01.25 & 01.25 & 01.25 \\
\hline 2. & Caste based occupation & 01.25 & 01.25 & 01.25 & 01.25 \\
\hline 3. & Service & 18.75 & 00.00 & 25.00 & 01.25 \\
\hline 4. & Agriculture & 55.00 & 25.00 & 37.50 & 27.50 \\
\hline 5. & Business & 17.50 & 05.00 & 18.75 & 12.50 \\
\hline 6. & Dairying & 03.75 & 06.25 & 02.50 & 01.25 \\
\hline 7. & Agro based enterprise & 02.50 & 00.00 & 13.75 & 03.75 \\
\hline & Annual income of family & & & & \\
\hline 1. & Below- 75000 & & & & \\
\hline
\end{tabular}




\begin{tabular}{|c|c|c|c|c|c|c|}
\hline 2. & \multicolumn{2}{|l|}{ 75001-150000 } & \multicolumn{2}{|c|}{33.75} & \multicolumn{2}{|c|}{15.00} \\
\hline 3. & \multicolumn{2}{|l|}{$150001-225000$} & \multicolumn{2}{|c|}{17.50} & \multicolumn{2}{|c|}{63.75} \\
\hline 4. & \multicolumn{2}{|l|}{$225001-300000$} & \multicolumn{2}{|c|}{15.00} & \multicolumn{2}{|c|}{12.50} \\
\hline \multirow[t]{2}{*}{5.} & \multicolumn{2}{|l|}{ 300001- above } & \multicolumn{2}{|c|}{07.50} & \multicolumn{2}{|c|}{05.00} \\
\hline & \multicolumn{2}{|c|}{ Communication media possession } & F \% & $\mathbf{P} \%$ & F \% & $\mathbf{P} \%$ \\
\hline 1 & \multicolumn{2}{|c|}{ News paper } & 90.00 & 81.25 & 93.75 & 96.25 \\
\hline 2 & \multirow{2}{*}{\multicolumn{2}{|c|}{$\begin{array}{l}\text { Radio } \\
\text { Television }\end{array}$}} & 87.50 & 40.00 & 76.25 & 72.25 \\
\hline 3 & & & 48.75 & 85.00 & 92.50 & 97.25 \\
\hline 4 & \multicolumn{2}{|l|}{ Computer } & 25.00 & 45.00 & 66.25 & 76.25 \\
\hline 5 & \multicolumn{2}{|l|}{ Magazine } & 31.25 & 47.50 & 40.00 & 75.00 \\
\hline 6 & \multicolumn{2}{|l|}{ Book } & 15.00 & 97.50 & 47.50 & 100.0 \\
\hline 7 & \multicolumn{2}{|l|}{ Journal } & 00.00 & 23.75 & 10.00 & 30.00 \\
\hline 8 & \multicolumn{2}{|l|}{ Telephone } & 25.00 & 15.00 & 43.75 & 36.25 \\
\hline 9 & \multicolumn{2}{|l|}{ Cellular phone } & 87.50 & 91.25 & 96.25 & 97.50 \\
\hline \multirow[t]{2}{*}{10} & \multicolumn{2}{|l|}{ Periodicals } & 07.50 & 08.75 & 12.50 & 18.75 \\
\hline & \multicolumn{6}{|l|}{ Land holding } \\
\hline 1. & \multicolumn{2}{|l|}{ Land less } & & .50 & & 3.75 \\
\hline 2. & Marginal (below 1 hect.) & & & .00 & & 5.00 \\
\hline 3. & Small (1-2 hect.) & & & .75 & & 2.50 \\
\hline 4. & Medium (2-3 hect.) & & & .50 & & 3.75 \\
\hline 5. & Large(3hect.- above) & & & .25 & & 5.00 \\
\hline & Decision pattern of family & Father & Mother & Brother & Self & Sister \\
\hline A. & Family affairs & & & & & \\
\hline 1. & Housing & 75 & 80 & 05 & 00 & 00 \\
\hline 2. & Fooding & 68 & 89 & 03 & 00 & 00 \\
\hline 3. & Health matters & 94 & 66 & 00 & 00 & 00 \\
\hline 4. & Education & 120 & 37 & 03 & 00 & 00 \\
\hline 5. & Entertainment & 97 & 58 & 03 & 01 & 01 \\
\hline B. & Agricultural matters & & & & & \\
\hline 1. & Crop sowing & 109 & 26 & 00 & 00 & 00 \\
\hline 2. & Purchasing & 100 & 34 & 00 & 01 & 00 \\
\hline 3. & Ploughing & 100 & 34 & 01 & 00 & 00 \\
\hline 4. & Storage & 92 & 37 & 06 & 00 & 00 \\
\hline C. & Occupational matters & & & & & \\
\hline 1. & Services & 121 & 31 & 02 & 06 & 00 \\
\hline 2. & Business & 130 & 22 & 06 & 00 & 02 \\
\hline 3. & Agriculture & 140 & 19 & 01 & 00 & 00 \\
\hline
\end{tabular}




\section{Role of family environment about rural girl's students}

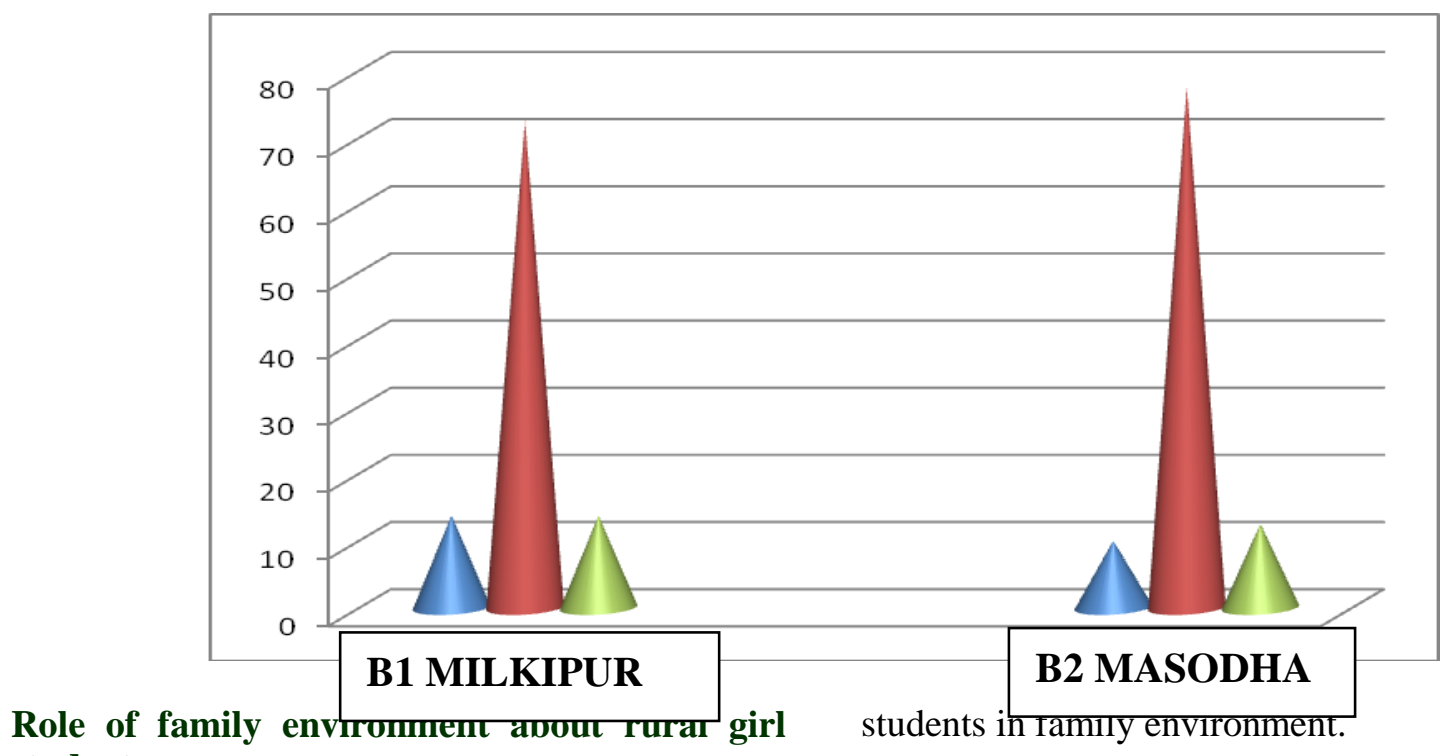

\section{students}

Table. 2 indicates that the majority of respondents in Milkipur block (72\%) and Masodha block (77\%) had medium level of family environment followed by low $(13 \%, 10 \%)$ and high $(13 \%$, $12 \%$ ) respectively. The mean of scores for family environment was found to be 273.06 (Milkipur) 272.2 (Masodha).

It can be concluded the girl students, data depicted that there was no caste discrimination as far as admission in high school, intermediate and graduation. Majority of students were found more conscious for married life. Father was observed most important motivational sources. Most of guardians were medium category land holding, having agriculture as family occupation. The economic and value orientations were observed of medium level means that there was no discrimination in the observed data. Most of students in communication were found more conscious for book and father deicide all matter of family. The medium level preferred most of

\section{References}

Agarwal, J.C. 1976. Indian women education and status, Man Singh Arya Book Depot, New Delhi.

Ahuja, P.K. 1995. Women and sustainable development, Ashish publishing house. New Delhi.

Devi, Rajula. 1982. Women in rural industries, Kurukshetra, Vol. XXX, No. 23, Sep, 1: 1316.

Errooh, Wendy, K., Roland and Chotherine, B. 2006. Social adjustment of college freshmen. The importance of gender and living environment. College student J., 40(1): 43-54.

Pandey, D. 1995. Girl child family in Maharastra, J. Social Charge, 25(2\& 3): 217-225.

Sikka, P., Dixit, V.B., Sharma, R.K., Maurya, A. 2013. Rural women and Buffalo Rearing Kurukshetra, Vol. 55, p. 34.

\section{How to cite this article:}

Shalini Srivastava, Prakash Singh and Manoj Kumar. 2017. Situational Effect about Rural Girls in Faizabad District. Int.J.Curr.Microbiol.App.Sci. 6(2): 1648-1654. doi: http://dx.doi.org/10.20546/ijcmas.2017.602.184 